\title{
Empirical Analysis in the Political Connection and the Performance of Merger and Acquisition
}

\author{
Zhentang Zhong \\ College of Economics, Jinan University, Guangzhou, China \\ Email: 549244883@qq.com
}

Received 15 December 2015; accepted 31 January 2016; published 3 February 2016

Copyright (C) 2016 by author and Scientific Research Publishing Inc.

This work is licensed under the Creative Commons Attribution International License (CC BY).

http://creativecommons.org/licenses/by/4.0/

c) (i) Open Access

\begin{abstract}
As the domestic capital market starts late, relative to perfect foreign capital markets, there is relatively less study on Merger and Acquisition (M \& A), and there is more lacking in related research on the impact of non-economic factors such as corporate culture and political connection on the performance of $M \& A$. This paper supplements vacancy related fields through the study on impact of relations between enterprises and governments on the performance of $M \& A$. Taking $M \& A$ events launched by China's A-share listed companies from 2007 to 2011 as samples, this paper uses operating cash flow return on total assets to measure a company's performance and testing is performed by multiple regression analysis; the results show that the political connection degree of general manager or chairman has no significant impact on the performance after $M \& A$, while has a significant positive impact on the performance of $M \& A$ in private enterprises.
\end{abstract}

\section{Keywords}

Political Connection, Performance of Merger and Acquisition, Private-0wn Enterprise

\section{Introduction}

Enterprises often use internal resources or external resources to expand in their development process in order to achieve scale effect and to seek long-term development of enterprises. In expansion of Western companies, Merger and Acquisition (M \& A) is a major way, and there have been numerous researches on the impact of $\mathrm{M}$ \& A on corporate performance abroad. However, China's capital market has started late, and the rules system is imperfect; thus research on the performance of $\mathrm{M} \& \mathrm{~A}$ is also relatively lacking.

Existing research on the performance of M \& A focuses on two aspects; one is selection of measurement in- 
dex for the performance of M \& A, and another one is study on factors influencing the performance of M \& A. Study on factors affecting the performance of $M$ \& A mainly focuses on discussing impact of factors such as business ownership structure, capital structure and corporate governance on the performance of $M$ \& A, while there is less research on impact of political connection on the performance of M \& A. In fact, because the Chinese society is in special period of transition economy and has social and cultural traditions of stressing "human feelings” and "relationship”, social capital brought by government-relevance to the enterprises shows strong explanatory power for phenomena in China's economy and society. A large number of studies have shown that enterprises enjoy more advantages such as taxes, financing, and cross-industry business and so on with high political connections, but there are also deficiencies of lower operating efficiency. In addition, although there are few studies in this area currently, they only regard political connection as a dummy variable to study the relationship between the two, and there is no precise quantification of the variable-political connection.

In view of the above discussion, this article will use Analytic Hierarchy Process (AHP) analysis method to build exquisite political connection index so as to study of the issue of the performance of $\mathrm{M} \& \mathrm{~A}$ in government-linked companies. In addition, we use AHP methods to measure the degree of political connection of chairman and general manager respectively. We use chairman-political connection and general managerpolitical connection to be the representation of the degree of political connection of chairman and general manager in this study.

Firstly, we will study difference in impact of political connection degree between chairman and general manager on the performance of $\mathrm{M} \& \mathrm{~A}$, and then study difference in impact of political connection on the performance of $\mathrm{M} \& \mathrm{~A}$ in private-owned enterprises and non-private-owned enterprises.

\section{Literature Review and Research Hypothesis}

Currently, there are a growing number of researches on political connection, but there is temporarily no conclusive data whether political connection will bring positive or negative impact on enterprises in short-term or long-term, and documents research results related to political connection are collected here to determine whether government-relevance will bring positive or negative impact on enterprises and to demonstrate research results by category.

\subsection{Political Connection Brings Positive Impacts on Enterprises}

A considerable part of scholars believe that political connection will provide convenience for corporate development in all aspects to facilitate their better performance. For example, after the study on global 47 countries, Faccio et al. [1] have found that political connection is a common phenomenon, and especially in emerging market countries, government-linked companies often have stronger competitive advantages such as more favorable loan rates, lower tax rates and higher market share, while he has found that the higher the level entering the politics, the more intense the company's market reaction will be. Li et al. [2] believe that relation is an informal system, and there is certain substitutability between it and the formal system, and it can reduce corporate uncertainty to some extent and reduce transaction costs. Claessens et al. [3] believe that since the government holds the power of resources allocation, political connected enterprises can take higher priority to receive government orders, to get more subsidies and more tax breaks. Park and Luo [4] have found that political connection is the alternative of backward legal mechanism in some way, helping enterprises to protect their rights, so as to be conducive to increasing the value of the business.

There are also related researches on impact of political connection. Xuyang $\mathrm{Hu}$ [5] has conducted research with top 100 private enterprises in Zhejiang Province in 2004 as samples, and research results show that the political connected private enterprises can deliver positive signal of credit quality, thus they will obtain handier financing. Guangyong Lei et al. [6] has taken A-share listed companies in 2003-2005 as the research object and found that in the case of the low level of government by law, political connection has greater positive impact on corporate value. Min Zhang and Jicheng Huang [7] have studied found that the government-linked companies have higher degree of diversification than the non-government-linked companies, which prove that governmentlinked companies can obtain more diversified resources. Danglun Luo and Xiaolong Liu [8] have conducted research with private listed companies in 2004-2006 as samples, and the results show that government-linked private enterprises can more easily enter the government-controlled high profit industries, thereby improving the corporate performance. Minggui Yu et al. [9] have found that when the capital occupying for controlling share- 
holders never occurs, political connection has a positive impact on the company’s performance.

\subsection{Political Connection Brings Negative Impacts on Enterprises}

Research on the negative impact of political connection on enterprises is basically expounded from the perspective of impact of political connection on operating decision and efficiency inside the enterprises. Faccio et al. [1] believes that although the government-affiliated enterprises have easier access to government support after plunging into a sorry plight, there is a significant decline in performance after gaining the support and it is significantly lower than that in non-government-linked companies. Marianne et al. [10], taking listed companies in France as research subjects, has found that in order to reap the continued benefits of political connection, government-linked companies have to pay more associated costs to maintain the political connection, thereby reducing the efficiency of corporate application of funds.

There are some relevant literatures on the adverse effects of political connection on business operation in China. Jiaxing You et al. [11] have analyzed changes in 842 executives in1998-2008, and the results show that government-linked companies have increased the entrenchment effect of senior executive departing and reduced the company's performance. Hongbo Pan and Minggui Yu [12] have carried out research on A-share listed private enterprises in 2001-2005 and found that government-affiliated listed private enterprises have lower costs of shareholders' interest transfer, thereby enhancing the possibility of their transfer of benefits and reducing corporate performance. Min Zhang et al. [13] has studied and found that although the government-linked companies can obtain convenient bank loans, they also make more excessive investments, thus reducing the using efficiency of corporate credit funds. The study of Xingqiang Du et al. [14] has found that there is a significant positive relationship between political connection and corporate excessive investment. The study of Jianhua Guo [15] has found that government-affiliated private listed companies will bear more policy burdens relatively, increase unnecessary costs and reduce performance.

In terms of the relevant literatures, political connection will truly influence the entrepreneurial behaviors of investment and financing and expansion, and has obvious impact on private enterprises; $\mathrm{M} \& \mathrm{~A}$ is an important form of business expansion, and it will inevitably be associated with political connection to some extent. By reference to the conclusions of relevant literature, this paper makes the following several assumptions:

Hypothesis 1: Chairman-political connection has significant positive impacts on the performance of $\mathrm{M} \& \mathrm{~A}$ in listed companies.

Hypothesis 2: General manager-political connection has significant positive impacts on the performance of M \& A in listed companies.

Hypothesis 3: Political connection has significant positive impacts on the performance of M \& A in privateowned enterprises.

\section{Research Design}

\subsection{Sample Treatment}

M \& A studied in this paper include asset acquisition, share acquisition and consolidation by merger. The object of this study is listed companies in Shanghai and Shenzhen in 2007-2011, and the selection of 2007 as the starting year mainly considers the implementation of the new accounting standards in that year, so as to ensure consistency of accounting policies during the study period; selecting 2011 as the year of termination is out of the consideration that the study on performance in three years after the $\mathrm{M} \& \mathrm{~A}$ is required. Data related to $\mathrm{M}$ \& $\mathrm{A}$ are obtained from CSMAR database. Furthermore, referring to the operation of the relevant literature, this paper filters the original data as follows:

1) Eliminate samples that bidders are financial and non-bank financial companies.

2) The ratio of $M \&$ \& transactions amount to total assets of acquiring firm is not less than $4 \%$.

3) The bidder achieves relative holding of the target company after $\mathrm{M} \& \mathrm{~A}$, and equity ratio of bidder after $\mathrm{M}$ \& A is greater than $30 \%$.

4) For multiple $M \& A$ completed in the same company and at the same year, the sample of the largest amount is retained.

5) Eliminate the relevant missing information and sample data of unknown resume information of executives.

6) Eliminate samples of related transactions. 
7) Eliminate ST (Specialtreatment) and ${ }^{\text {ST }}$ listed companies.

8) Eliminate B-share listed companies.

\subsection{Variable Description}

The methods to measuring the performance of $\mathrm{M} \& \mathrm{~A}$ are mainly market approach and accounting law currently. Shanmin Li et al. [16] have pointed out that the market approach is to measure the performance of M \& A with long stock returns in event period, but the premise is that stock market effective, while there is a gap between China's capital market and foreign mature capital market. Therefore, this paper uses operating cash flow return on total assets to measure the performance of $\mathrm{M} \& \mathrm{~A}$, and this may also avoid distortion of accounting information caused by changes in earnings management and accounting policy in addition to avoiding the validity of the securities market. Table 1 shows the type, name, symbol and measure method of variables.

\subsection{Model Specification}

To test the hypothesis 1 and 2, we have taken operating cash flow return on total assets as dependent variable and general manager-political connection index and chairman-political connection index as the independent variables respectively, while five control variables including LnAsset (Natural logarithm of total assets), Leverage (Total debt/total assets), BM (Book-to-Market ratio), TQ (Tobin's q) and Private (Whether the company is private-owned) are introduced; additionally, annual dummy variables are added to control impact of economic trends at different years on the performance of $\mathrm{M} \& \mathrm{~A}$; 1 is taken as the dummy variable of year_1 to year_4 to indicate 2007 to 2010 respectively. Equation (1) established is as follows:

$$
\begin{aligned}
\text { CFR }_{i, t+1}= & \beta_{0}+\beta_{1} \text { ChairPCIndex }_{i}+\beta_{2} \text { Private }_{i}+\beta_{3} \text { LnAsset }_{i, t-1}+\beta_{4} \text { Leverage }_{i, t-1}+\beta_{5} T Q_{i, t-1} \\
& +\beta_{6} B M_{i, t-1}+\beta_{7} \text { Year_ }_{-} 1_{i}+\beta_{8} \text { Year }_{-} 2_{i}+\beta_{9} \text { Year }_{-} 3_{i}+\beta_{10} \text { Year }_{-} 4_{i}+\varepsilon_{i, t}
\end{aligned}
$$

In Equation (1), $i$ is the number of $\mathrm{M} \& \mathrm{~A}$ events and $t$ is the acquisition of the year; $C F R_{i, t+1}$ indicates the operating cash flow return on total assets exceeding corresponding value in the previous year one year after the occurrence of $\mathrm{M} \& \mathrm{~A}$ event, showing improved conditions of business instances to measure the performance of M \& A. When $\beta_{1}$ in Equation (1) is significantly positive, it indicates that the greater the degree of corporate Chairman-political connection is, the greater the degree of performance improvement after $\mathrm{M} \& \mathrm{~A}$ will be. ChairPCIndex $_{i}$ is replaced for CEOPCIndex ${ }_{i}$ to establish Equation (2) as follows:

$$
\begin{aligned}
\text { CFR }_{i, t+1}= & \beta_{0}+\beta_{1} \text { CEOPCIndex }_{i}+\beta_{2} \text { Private }_{i}+\beta_{3} \text { LnAsset }_{i, t-1}+\beta_{4} \text { Leverage }_{i, t-1}+\beta_{5} \text { TQ }_{i, t-1} \\
& +\beta_{6} \text { BM }_{i, t-1}+\beta_{7} \text { Year }_{-} 1_{i}+\beta_{8} \text { Year }_{-} 2_{i}+\beta_{9} \text { Year }_{-} 3_{i}+\beta_{10} \text { Year }_{-} 4_{i}+\varepsilon_{i, t}
\end{aligned}
$$

when in $\beta_{1}$ Equation (2) is significantly positive, it indicates that the greater the degree of general managerpolitical connection is, the greater the degree of performance improvement after $\mathrm{M} \& \mathrm{~A}$ will be. Adding

\begin{tabular}{|c|c|c|c|}
\hline Variable type & Variable name & Variable symbol & Variable measure method \\
\hline Explained variable & Operating cash flow return on total assets & CFR & Operating cash flow/total assets \\
\hline \multirow[t]{3}{*}{ Explanatory variable } & Political connection index of chairman & PCIndex_Chair & $\begin{array}{l}\text { Obtaining political l connection index of } \\
\text { chairman and CEO by using analytic }\end{array}$ \\
\hline & Political connection index of CEO & PCIndex_CEO & hierarchy process (ahp). \\
\hline & Whether the company is private-owned & Private & $\begin{array}{l}\text { If the company is private-owned, recorded } \\
\text { as } 1 \text {, otherwise to } 0 \text {. }\end{array}$ \\
\hline \multirow[t]{4}{*}{ Control variable } & Company size & LnAsset & Natural logarithm of total assets \\
\hline & Leverage ratio & Leverage & Total debt/total assets \\
\hline & Book-to-Market ratio & $\mathrm{BM}$ & It is the reciprocal of the price/book value ratio \\
\hline & Tobin’s q & TQ & Enterprise value/asset replacement cost \\
\hline
\end{tabular}

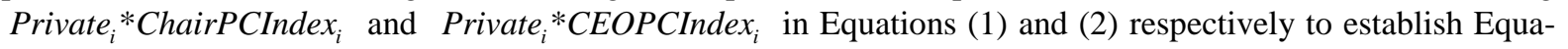
tions (3) and (4) as follows:

Table 1. Variable description table. 


$$
\begin{aligned}
& \text { CFR }_{i, t+1}=\beta_{0}+\beta_{1} \text { ChairPCIndex }_{i}+\beta_{2} \text { Private }_{i}+\beta_{3} \text { Private }_{i} * \text { ChairPCIndex }_{i} \\
& +\beta_{4} \text { LnAsset }_{i, t-1}+\beta_{5} \text { Leverage }_{i, t-1}+\beta_{6} T Q_{i, t-1}+\beta_{7} B M_{i, t-1}+\beta_{8} \text { Year }_{-} 1_{i} \\
& +\beta_{9} \text { Year_ } 2_{i}+\beta_{10} \text { Year_ } 3_{i}+\beta_{11} \text { Year } \_4_{i}+\varepsilon_{i, t} \\
& \text { CFR }_{i, t+1}=\beta_{0}+\beta_{1} \text { CEOPCIndex }_{i}+\beta_{2} \text { Private }_{i}+\beta_{3} \text { Private }_{i} * \text { CEOPCIndex } \\
& +\beta_{4} \text { LnAsset }_{i, t-1}+\beta_{5} \text { Leverage }_{i, t-1}+\beta_{6} T Q_{i, t-1}+\beta_{7} B M_{i, t-1}+\beta_{8} \text { Year }_{-} 1_{i} \\
& +\beta_{9} \text { Year } \_2_{i}+\beta_{10} \text { Year_ } 3_{i}+\beta_{11} \text { Year_ } 4_{i}+\varepsilon_{i, t}
\end{aligned}
$$

when $\beta_{3}$ in Equations (3) and (4) is significantly positive, it indicates that political connection has significant positive impacts on the performance of M \& A in private-owned listed companies.

\section{Hypothesis Test and Regression Result Analysis}

\subsection{Descriptive Statistics}

Table 2 divides samples into two categories according to whether the company is private-owned and lists the consequence of variables' descriptive statistics. As can be seen from the mean from $C F R_{t}$ to $C F R_{t+3}$, the performance of $M \& A$ in private-owned enterprise at the year of $M \& A$ and a year after $M \& A$ is worse than that in non-private enterprises, but the performance of $M \& A$ in private-owned enterprises from the second year to the third year after M \& A is better. Chairman-political connection index of private-owned enterprises is less than that in the non-private-owned enterprises, indicating that private-owned enterprises have relatively weaker degree of political connection. The average BM value of private-owned enterprises is lower, indicating its higher price/book value ratio. Private-owned enterprises have significantly higher leverage than non-private-owned enterprises, indicating that private-owned enterprises have higher debt ratio. At the same time, TQ value in private-owned enterprises is also significantly higher, which can be considered that private-owned enterprises have higher investment spending.

\subsection{Correlation Test}

Table 3 shows the correlation between the variables by using Spearman correlation test. We can find that CEOPCindex and ChairPCindex are weakly negatively correlated with Operating cash flow return on total assets(CFR1), but this is not significant, indicating that the impact of political connection level for corporate executives is small. LnAsset and BM are greater negatively correlated with Operating cash flow return on total assets(CFR1) with higher significance.

In addition, the correlation between the two independent variables of CEOPCindex and ChairPCindex is 0.2151 and they are not highly correlated. At the same time, the correlation coefficient between the other control variables is no more than 0.4 , indicating that there is no issue of multicollinearity in the model.

Table 2. The result of descriptive statistics.

\begin{tabular}{cccccccccccc}
\hline Private & & CFR0 & CFR1 & CFR2 & CFR3 & CEOPCINDEX & CHAIRPCINDEX & LNASSET & BM & LEVERAGE & TQ \\
\hline & Mean & -0.0226 & 0.0356 & 0.0471 & 0.0193 & 0.0043 & 0.0114 & 20.917 & 0.2061 & 398.95 & 10.130 \\
& Median & -0.0008 & 0.0018 & -0.0028 & 0.0076 & 0.0000 & 0.0000 & 20.866 & 0.1906 & 45.676 & 2.3995 \\
1 & Max & 1.0324 & 4.0641 & 5.0192 & 2.5770 & 0.0860 & 0.2497 & 23.829 & 1.4918 & 101319 & 2123.8 \\
& Min & -14.915 & -0.5450 & -2.0863 & -2.7789 & 0.0000 & 0.0000 & 12.314 & -1.1041 & 1.7795 & 0.2409 \\
& S.D. & 0.6295 & 0.3083 & 0.5617 & 0.2987 & 0.0113 & 0.0315 & 1.2043 & 0.2101 & 5748.9 & 120.44 \\
\hline & Mean & 0.0725 & 0.0672 & 0.0035 & -0.0865 & 0.0046 & 0.0182 & 21.787 & 0.2471 & 53.339 & 2.3026 \\
& Median & 0.0110 & -0.0075 & 0.0002 & -0.0068 & 0.0000 & 0.0000 & 21.672 & 0.2158 & 52.823 & 1.5329 \\
0 & Max & 37.8951 & 37.8094 & 37.8653 & 38.122 & 0.1244 & 0.2497 & 26.163 & 1.0477 & 674.05 & 35.145 \\
& Min & -1.8439 & -1.6954 & -24.291 & -62.153 & 0.0000 & 0.0000 & 16.962 & -0.4471 & 2.0744 & 0.1985 \\
& S.D. & 1.3497 & 1.3804 & 1.8191 & 3.3484 & 0.0134 & 0.0402 & 1.2956 & 0.1754 & 36.485 & 2.4975
\end{tabular}


Table 3. Spearman correlation test.

\begin{tabular}{|c|c|c|c|c|c|c|c|c|}
\hline & CFR1 & CEOPCINDEX & CHAIRPCINDEX & $\mathrm{BM}$ & LEVERAGE & LNASSET & TQ & PRIVATE \\
\hline CFR1 & 1.00 & & & & & & & \\
\hline CEOPCINDEX & -0.02 & 1.00 & & & & & & \\
\hline CHAIRPCINDEX & -0.02 & $0.21^{* * *}$ & 1.00 & & & & & \\
\hline $\mathrm{BM}$ & $-0.05^{* *}$ & -0.01 & 0.00 & 1.00 & & & & \\
\hline LEVERAGE & 0.00 & -0.01 & -0.02 & $-0.09^{* * *}$ & 1.00 & & & \\
\hline LNASSET & $-0.10^{* * *}$ & $0.08^{* * *}$ & $0.14^{* * *}$ & $0.35^{* * *}$ & $-0.26^{* * *}$ & 1.00 & & \\
\hline $\mathrm{TQ}$ & 0.00 & -0.02 & -0.02 & $-0.09^{* * *}$ & $0.37^{* * *}$ & $-0.27^{* * *}$ & 1.00 & \\
\hline PRIVATE & $0.015^{*}$ & -0.01 & $-0.09^{* * *}$ & $-0.10^{* * *}$ & $0.04^{*}$ & $-0.32^{* * *}$ & $0.04^{*}$ & 1.00 \\
\hline
\end{tabular}

Note: ${ }^{*},{ }^{* *}$ and ${ }^{* * *}$ show that test result is respectively significant at level $10 \%, 5 \%, 1 \%$.

\subsection{Empirical Result Analysis}

This article will examine the impact of relations between enterprises and governments on the performance of $\mathrm{M}$ \& A in acquiring company through the establishment of multiple linear regression model. Table 4 shows OLS regression result. Second and third columns of the table primarily test the impact of chairman-political connection and general manager-political connection on the performance of M \& A in listed companies. In the fourth column and the fifth column, we have added cross multiply items of political connection and private-owned or not (CEOPCindex*Private and ChairPCindex*Private), in order to examine the differences in impact of political connection on the performance of $\mathrm{M} \& \mathrm{~A}$ in private-owned enterprises and non-private-owned enterprises. In the second and third columns, the coefficients of ChairPCindex and CEOPCindex are negative $(-0.325005$ and -0.817529) but not significant, which indicates that compared to listed companies without political connection, listed companies with political connection have even worse performance of $\mathrm{M} \& \mathrm{~A}$, but this difference is not significant. That is, the government-backed executives do not bring a significant impact on the performance of M \& A in listed companies, thereby rejecting the Hypotheses 1 and 2.

With respect to the insignificant impact of political connection on the performance of M \& A in listed companies, the reason is that the costs paid by enterprises to establish and maintain political connection and gains brought by political connection offset each other. Political connection can ease financing constraints of enterprises, providing important financial support for the implementation of $\mathrm{M} \& \mathrm{~A}$, but also can help enterprises to enter the government-regulated industry, thus contributing to its implementation of diversified $\mathrm{M} \& \mathrm{~A}$, which have helped improve the performance of M \& A. However, at the same time, establishing and maintaining political connection needs to pay certain costs. Relaxed financing environment may cause overconfidence in enterprise managers, thereby inducing its implementation of M \& A bad for long-term development of enterprises; in addition, political connection makes easier government intervention in business, forcing enterprises to implement some unscientific M \& A bad for their own development in order to improve performance of government officials, thus reducing the performance of $\mathrm{M} \& \mathrm{~A}$. Therefore, ultimate impact of political connection on the performance of M \& A in listed companies depends primarily on the comparison between two forces of political connection. Seen from the regression results of this paper, the various costs paid by enterprises to establish and maintain political connection are likely to have offset the various beneficial effects of the political connection on the enterprises, thus we obtaining negative correlation of political connection and non-significant impact.

In the fourth and the fifth columns of the table, we have added cross multiply items of political connection and private-owned or not (CEOPCindex*Private and ChairPCindex*Private). As can be seen from the regression results, coefficient of ChairPCindex*Private and CEOPCindex*Privateat is significantly positive $(0.793494$ and 1.039044) at confidence level $10 \%$, indicating that in the M \& A of private-owned enterprises, the political connection can significantly increase the performance of M \& A in private-owned listed companies, thus hypothesis 3 holds. It is worth noting that after the addition of cross-multiplication term, the coefficient of ChairPCindex and CEOPCindex becomes smaller ( -0.577372 and -1.175469$)$, which shows that direct impact 
Table 4. Regression results of model (1)-(4).

\begin{tabular}{|c|c|c|c|c|}
\hline & (1) & (2) & (3) & (4) \\
\hline & CFR1 & CFR1 & CFR1 & CFR1 \\
\hline \multirow[t]{2}{*}{ Constant } & $1.732338^{* * *}$ & $1.746577^{* * *}$ & $1.72752^{* * *}$ & $1.748788^{* * *}$ \\
\hline & (3.00475) & (3.044064) & $(2.995151)$ & (3.046455) \\
\hline \multirow[t]{2}{*}{ CHAIRPCINDEX } & -0.325005 & & -0.577372 & \\
\hline & $(-0.422224)$ & & $(-0.620999)$ & \\
\hline \multirow[t]{2}{*}{ CEOPCINDEX } & & -0.817529 & & -1.175469 \\
\hline & & $(-0.366406)$ & & $(-0.427233)$ \\
\hline \multirow[t]{2}{*}{ CHAIR $*$ PRI } & & & $0.793494^{*}$ & \\
\hline & & & $(1.74532)$ & \\
\hline \multirow[t]{2}{*}{ CEO*PRI } & & & & $1.039044^{*}$ \\
\hline & & & & $(1.72836)$ \\
\hline \multirow[t]{2}{*}{$\mathrm{BM}$} & -0.076057 & -0.075192 & -0.078376 & -0.074963 \\
\hline & $(-0.470814)$ & $(-0.465582)$ & $(-0.484831)$ & $(-0.464005)$ \\
\hline \multirow[t]{2}{*}{ LNASSET } & $-0.079019^{* * *}$ & $-0.079703^{* * *}$ & $-0.078531^{* * *}$ & $-0.079717^{* * *}$ \\
\hline & $(-3.00285)$ & $(-3.04649)$ & $(-2.9813)$ & $(-3.046011)$ \\
\hline \multirow[t]{2}{*}{ LEVERAGE } & $-0.000429^{*}$ & $-0.000427^{*}$ & $-0.000428^{*}$ & $-0.000426^{*}$ \\
\hline & $(-1.73665)$ & $(-1.729319)$ & $(-1.730768)$ & $(-1.723678)$ \\
\hline \multirow[t]{2}{*}{ TQ } & $0.020096^{*}$ & $0.019996^{*}$ & $0.020038^{*}$ & $0.019942^{*}$ \\
\hline & (1.700283) & (1.692818) & (1.694787) & (1.687367) \\
\hline \multirow[t]{2}{*}{ PRIVATE } & $0.106593^{*}$ & $0.105375^{*}$ & $0.117046^{*}$ & $0.109979^{*}$ \\
\hline & $(1.764342)$ & $(1.744362)$ & (1.823974) & $(1.721822)$ \\
\hline \multirow[t]{2}{*}{ YEAR_1 } & 0.079864 & 0.077047 & 0.080435 & 0.076505 \\
\hline & (0.880079) & $(0.853549)$ & $(0.886067)$ & $(0.846963)$ \\
\hline \multirow[t]{2}{*}{ YEAR_2 } & 0.013809 & 0.010738 & 0.011098 & 0.010137 \\
\hline & $(0.154006)$ & $(0.119851)$ & $(0.123492)$ & $(0.113044)$ \\
\hline \multirow[t]{2}{*}{ YEAR_3 } & 0.14915 & 0.148611 & 0.148362 & 0.148862 \\
\hline & (1.59597) & $(1.590443)$ & $(1.586874)$ & (1.592495) \\
\hline \multirow[t]{2}{*}{ YEAR_4 } & 0.034429 & 0.033703 & 0.034132 & 0.033451 \\
\hline & $(0.387327)$ & $(0.379154)$ & $(0.383874)$ & $(0.376157)$ \\
\hline
\end{tabular}

Note: ${ }^{* * *}$ and ${ }^{* * *}$ show that regression result is respectively significant at level $10 \%, 5 \%, 1 \%$; $\mathrm{T}$ statistics are shown in brackets.

of political connection on the performance of M \& A in listed companies is negative; however, impact on the performance of M \& A in private-owned listed companies is positive. This is mainly because most of the private enterprises are lacking in political connection. Therefore, government-linked private-owned enterprises have more advantages in loans, tax and other aspects.

\section{Conclusions and Suggestions}

From an overall perspective, the government-backed executives fail to bring significant impact on the performance of M \& A in listed companies. Although political connection can ease financing constraints of listed companies and help businesses access to government-regulated industry so as to improve long-term performance of M \& A, political connection may also cause excessive investment in listed companies; thus they would be 
engaged in some M \& A projects bad for corporate long-term development, and government intervention brought by political connection would also bring a negative impact on the performance of M \& A in listed companies. Therefore, positive and negative effects of political connection may cancel each other out, thus the impact of political connection on the performance of $\mathrm{M} \& \mathrm{~A}$ becomes non-significant.

In M \& A of private enterprises, the political connection can significantly increase the performance of $\mathrm{M}$ \& $\mathrm{A}$ in private-owned listed companies. In China, some high-profit industries have been under strict control of the government. With the unceasing deepening of reform and opening up, the government is gradually relaxing barriers to enter these regulated industries. Strong government background can help private companies get easier access to these high-profit industries to gain broader spaces for development, thereby improving the performance of $M \& A$.

Study in this paper shows that although political connection can bring a positive influence on the performance of M \& A in the private-owned enterprises; however, when more private-owned enterprises win political connection, the advantages of tax, financing and other aspects will disappear, and the negative impact of political connection will appear. Therefore, private-owned enterprises should view the various effects caused by political connection in more comprehensive and rational manner. More importantly, private-owned enterprises should focus on their core business to achieve various development strategies through their own efforts, rather than to seek to build and maintain political connection in search of various rents with single-minded purpose. Only in this way can private-owned enterprises obtain long-term sustainable development.

The government should take and strictly implement various policies and measures to eliminate phenomena of discrimination against the private economy in the real economy and to continue to improve property rights and the system of legal protection. Only with a favorable external environment, private-owned enterprises can mainly focus on their own production and business activities, instead of excessive pursuit of political connection. Excessive pursuit of political connection for private enterprises is not only easy to breed corruptions, but also to lead to distortions in social allocation of credit resources, thereby reducing the benefit level of the entire society.

\section{References}

[1] Faccio, M., Masulis, R.W. and McConnell, J. (2006) Political Connections and Corporate Bailouts. The Journal of Finance, 61, 2597-2635. http://dx.doi.org/10.1111/j.1540-6261.2006.01000.x

[2] Li, H., Meng, L. and Zhang, J. (2006) Why Do Entrepreneurs Enter Politics? Evidence from China. Economic Inquiry, 44, 559-578. http://dx.doi.org/10.1093/ei/cbj031

[3] Claessens, S., Feijen, E. and Laeven, L. (2008) Political Connections and Preferential Access to Finance: The Role of Campaign Contributions. Journal of Financial Economics, 88, 554-580. http://dx.doi.org/10.1016/j.jfineco.2006.11.003

[4] Park, S.H. and Luo, Y. (2001) Guanxi and Organizational Dynamics: Organizational Networking in Chinese Firms. Strategic Management Journal, 22, 455-477. http://dx.doi.org/10.1002/smj.167

[5] Hu, X.Y. (2006) Political Identity of Private Entrepreneurs and Financing Convenience of Private-Owned FirmsTaking Top 100 Private-Owned Firms in Zhejiang Province for Example. Management World, 5, 107-113. (In Chinese)

[6] Lei, G.Y., Li, S.F. and Wang, X.J. (2009) Political Connection, Choose of Auditor and Enterprise Value. Management World, 7, 145-155. (In Chinese)

[7] Zhang, M. and Huang, J.C. (2009) Political Connection, Diversification and Business Risk-Empirical Evidence Based on Stock Market in China. Management World, 7, 156-164. (In Chinese)

[8] Luo, D.L. and Liu, X.L. (2009) Political Connection, Barriers to Entry and Performance of Enterprise-Empirical Evidence Based on Private Listed Firms. Management World, 5, 97-106. (In Chinese)

[9] Yu, M.G., Hui, Y.F. and Pan, H.B. (2010) Political Connections, Rent Seeking, and the Fiscal Subsidy Efficiency of Local Governments. Economic Research Journal, 45, 65-77. (In Chinese)

[10] Bertrand, M., Kramarz, F., Schoar, A. and Thesmar, D. (2004) Politically Connected CEOs and Corporate Outcomes: Evidence from France. Unpublished Manuscript.

[11] You, J.X., Xu, P.P. and Chen, S.M. (2010) Political Connection, Position Entrenchment and Management TurnoverEmpirical Evidence Based on Financial Distress Listed Firms. Journal of Financial Research, 4, 128-143. (In Chinese)

[12] Pan, H.B. and Yu, M.G. (2010) Political Connections, Expropriation and the Performance of Private-Owned Firms. Nankai Business Review, 4, 14-27. (In Chinese) 
[13] Zhang, M., Zhang, S. and Wang, C.F. (2010) Political Connections and Credit Resources Allocation EfficiencyEmpirical Evidence Based on Private Listed Firms. Management World, 11, 143-153. (In Chinese)

[14] Du, X.Q., Zeng, Q. and Du, Y.J. (2011) Political Connections, over Investment and Corporate Value-Empirical Evidence Based on State-Owned Listed Companies. Journal of Financial Research, 8, 93-110. (In Chinese)

[15] Guo, J.H. (2011) Institutional Environments, Political Connections and Policy Burden-Empirical Evidence Based on Private Listed Firms. Journal of Shanxi Finance and Economics University, 7, 33-40. (In Chinese)

[16] Li, S.M., Zeng, Z.Z., Wang, C.P., et al. (2004) M \& A Performance of Listed Companies and Influencing Factors. Journal of World Economy, 27, 60-67. 